\title{
The Task of a Naturalist: An Epitaph for Philippa Foot (1920-2010)
}

\section{Piotr Makowski (Poznań)}

Philippa Foot once said: ?I?m not clever at all. I have a certain insight into philosophy, cost I think. But I?m not clever, click I don?t find complicated arguments easy to follow? (Baggini, 2003). Foot?s cleverness enticed many thinkers to take these Gombrowiczian lines seriously.

In her long and distinguished philosophical career, Foot authored just one regular book (Natural Goodness, 2001), and two volumes of collected papers. Known as one of the very best moral philosophers of the 2oth century, Foot is usually recognized as a critic of various forms of noncognitivism (Hare?s prescriptivism, Ayer-Stevenson?s emotivism, and, more recently, Gibbard?s expressivism), and as a ?grounder? of neo-Aristotelian virtue ethics (the trend famously revitalized by her friend and teacher ? G.E.M. Anscombe). Foot was a theoretician on euthanasia and abortion, and the author of the Trolley Problem thoughtexperiment. Of course, her philosophical career extended far beyond these typical problems of moral theory, especially when taken in a strictly philosophical way. It is no exaggeration to regard the picture of ethics she drew as a card to critical naturalism. This card says in nuce: there is nothing special in our morality that could make us, humans, really distinct from other living things. There is no specifically human dignity, and our rationality itself does not create any unusual standards different from other natural standards, if there are any. We are not special, and you can see this while observing our morality: Morality is ?defictionalized,? as Foot puts it not reluctantly (Foot, 1978, p. 174).

Of course, the task of grasping ethics in this naturalistic way is not so easy to solve ? and Foot?s own naturalistic account followed heedfully demonstrates that sufficiently. Anscombe?s pupil gave us more than one recipe: her approach to moral theory evolved into three distinctive periods (Lawrence 1995). Each of these periods, Early Foot, Middle Foot, and Late Foot, gave a different type of metaethical solution and a different naturalistic picture of morality. Aside from some consistent motives, such as refutation of the fact/value distinction, grounding the descriptive content of ethical judgments, virtues and vices-theme, we find three different attempts at solving the problem of ethical objectivity in her moral writings.

Having been inspired by the Humean theory of practical reason, Early Foot (Moral Arguments, Moral Beliefs, and Hume on Moral Judgement) developed Anscombe?s ideas on neo-Aristotelian virtue ethics in a very objectivist direction. Following Hume, Foot accepted the strong connection between human self-interest and virtues. This axiom made her prone to defending the view that no one ?could be indifferent to morality without error? (Foot, 1978, xiv): moral judgments necessarily give us reasons for moral action (Foot, 1978, p. 161). The naturalistic picture of morality that Foot offered was optimistic regarding the practical and universal relevance of ethical virtues. According to Foot, your desires are always in pursuance with virtue, so the latter is simply necessary for you. By actualizing virtuous existence, you fulfill your natural needs regarding biological being and social cooperation.

Middle Foot (Morality and Art, Morality as a System of Hypothetical Imperatives) came to doubt the strong link between virtues and self-interest, resulting in one of the most interesting and controversial proposals among modern theoreticians of ethics. Foot radicalized the Humean theory of reason: if you are to fulfill your individual needs, morality may become an obstacle for you (as in the case of being just). That is why morality is not practical in any distinctive sense: there is no ?automatic reason-giving force? built into moral judgments (Foot, 1978, pp. 156, 161). All that makes virtues valid are your individual will and your subjective drives: if you want to be moral, you can be, but nothing more: ?you should be moral? makes no sense. Morality is only for volunteers in the army of Kantian duty (Foot, 1978, p. 170). Although controversial, this naturalistic picture was more convincing than the former attempt: the nimbus and glory of morality disappear when virtue is a matter of willing, natural desires, pedagogy and self-discipline, and not a matter of mysterious inescapable ?ought? embedded in putative general human self-interest. But Middle Foot?s subjectivist proposal remained very problematic with regard to its general credibility as a descriptive theory of morality. It contradicted the intuitive idea of morality given commonly as a kind of demand. Foot needed to change the whole background of her ideas and put the discussion onto another level to solve the problem of objective morality.

The Oxfordian philosopher attempted to paint another naturalistic picture of virtues. But to make it possible, Foot required a set of completely different brushes. Her inspiration from David Hume?s notion of practical rationality had expired. She tried another direction ? Aristotle and biology. She came ?to see thoughts about goodness of human will and action that were the subject of moral philosophy as a particular case of the evaluation of other operations of human beings, and indeed of all living things considered ?in their own right? as connected to their own particular species-wide forms of life? (Foot, 2002, pp. 1f). The naturalistic picture of morality became unusually broad. In her one and only fully-fledged book, Natural Goodness, Foot again tried to defend the objectivistic understanding of ethics, having believed that moral judgements are only one sample of a whole class of natural evaluations pertaining to living things (Foot 2001). If you agree that one bunny which does not eat grass is a bad and defective bunny in comparison to one hundred other ?good? bunnies which ?do their duty?, you are also committed to the claim that one man who steals TV sets is a bad and defective man in comparison to ?good? men who do ?the whole duty of man?. There is no logical difference between these two types of evaluation (Foot, 2001, pp. 30?33). Late Foot tried to read the 
moral norms directly from nature itself, from ?the open book?, as the Ancients and Medievals did. Obviously, this quasibiological strategy must rely on a teleologically robust concept of ?human nature? a la Aristotle. But if you take modern biology seriously, this approach loses both its rhetorical and philosophical impact. Natural beings exist in their own way, never mind the circumstances that influence their shape, behavior, or action. If you remove yourself ? the observer of any being which could be condemned by you for not fulfilling its putative own mission? from the scene, you will not be able to go on to say that there is an objective goal in the existence of a bunny, and in human beings as well (cf. Lenman 2005). Surely, this naturalistic picture of the virtues in Late Foot seems very majestic: moral norms can be read out from nature, at least if you are reasonable enough to do so. But? majesty does not always mean authority or plausibility?

During her philosophical development, Foot presented at least three endeavors to give an acceptable, naturalistic picture of virtues: morality as it is. And the character of these endeavors debunks not only the specificity of investigation of morality, but also of naturalism itself. It is clear that there are too many accounts of naturalism to criticize this viewpoint under just one heading. Foot?s work shows perfectly that the naturalist?s task is not as simple as the critics of naturalism used to think. Although Footian metaethics bore many problems and handicaps throughout each stage of development, her naturalistic perspective in metaethics is no doubt attractive and practically important: thinking that there is a ?magic force? in moral duty relies on an illusion, for there is nothing special in our morality that makes us really distinct from other living things. And it fits well into Lawrence Solum?s opinion: Foot will be remembered ?not for a particular view or position, but for changing the way people think about topics? (Grimes 2010).

Philippa Ruth Foot (née Bosanquet), attended Somerville College, Oxford, in 1947, quickly gaining a tutorial fellowship, and then a research fellowship. In 1960, she moved to the United States, where she lectured at Berkeley, Cornell, New York, and Stanford. In 1976, she settled at UCLA in Los Angeles, where she remained for 15 years until her retirement in 1991 and received most of her philosophical recognition. Foot was awarded an Honorary Fellowship at Somerville College. She was the granddaughter of the U.S. President Grover Cleveland (for additional biographical information, see: Conradi \& Lawrence, 2010). Foot died in Oxford on October 3, 2010, the day of her birth, aged 90.

\section{Bibliography:}

Baggini, J. (2001). Philippa Foot (1920-2010). The Philosophers? Magazine, Issue: 21, retrieved from: http://www.philosophypress.co.uk/?p=1552.

Conradi, P. J., Lawrence, G. (2010). Professor Philippa Foot: Philosopher regarded as being among the finest moral thinkers of the age. The Independent, 19.10.2010, retrieved from: http://www.independent.co.uk/news/obituaries/professor-philippa-footphilosopher-regarded-as-being-among-the-finest-moral-thinkers-of-the-age-2110188.html.

Foot, Ph. (1978). Virtues and Vices and Other Essays in Moral Philosophy, Oxford: Blackwell.

Foot, Ph. (2001). Natural Goodness, Oxford: Clarendon Press.

Foot, Ph. (2002). Moral Dilemmas and Other Topics in Moral Philosophy, Oxford: Clarendon Press.

Grimes, W. (2010). Philippa Foot, Renowned Philosopher, Dies at 90. New York Times, 09.10.2010, retrieved from: http://www.nytimes.com/2010/10/10/us/10foot.html? r=1.

Lawrence, G. (1995). The Rationality of Morality. In: R. Hursthouse, G. Lawrence, \& W. Quinn (eds.), Virtues and Reasons. Philippa Foot and Moral Theory, Oxford: Clarendon Press, pp. 89?148.

Lenman, J. (2005). The Saucer of Mud, the Kudzu Vine, the Uxorious Cheetah: Against Neo-Aristotelian Naturalism in Metaethics. Electronic Journal of Analytic Philosophy, Vol. 1, No. 2, pp. 37?50. 